\title{
The Dilemma of Graduate Unemployment within a Context of Poverty, Scarcity and Fragile Economy: Are there Lessons for the University?
}

\author{
Marcellus Forh Mbah ${ }^{1}$ \\ ${ }^{1}$ Faculty of Education, Canterbury Christ Church University, Canterbury, United Kingdom \\ Correspondence: Marcellus Forh Mbah, Research Centre for Children, Families and Communities, Canterbury \\ Christ Church University, North Holmes Campus, CT1 1QU, United Kingdom. E-mail: \\ Marcellus.mbah@canterbury.ac.uk
}

Received: September 5, 2014

Accepted: October 7, 2014

Online Published: November 25, 2014

doi:10.5539/ijef.v6n12p27

URL: http://dx.doi.org/10.5539/ijef.v6n12p27

\begin{abstract}
The context of the work of universities in Sub-Saharan Africa is one of high levels of poverty, scarcities and fragile economies. Even though historically, African universities have been very useful in providing the human resources needed to serve in public and private sectors, the rising trend in graduate unemployment is a call for concern. Whilst graduate unemployment is also a phenomenon across the globe, the situation is particularly severe in Africa where many inhabitants see university education as a live wire to gain economic freedom, acquire prosperity and step into a better living condition. Whilst many Africans still harbour hope in tertiary education (and this can be evident by the increasing demand for university education and enrolment), the resulting effect of higher education is often an acquisition of prestige for having completed that level of education than the economic benefits they aspired for. Given this context, this article draws on a single interpretive case study involving a State-owned university, as well as semi-structured interviews and focus group discussions carried out with participants from disparate backgrounds to uncover voices on graduate unemployment, including the disturbing impact this phenomenon is having on families and the future of many youths. It concludes with recommendations of ways the university and its educational system can be fashioned to foster graduate employability and improvement in the living condition of those living in uncertain and fragile economies.
\end{abstract}

Keywords: university education, graduate employability, capacity building, entrepreneurship, Cameroon

\section{Introduction}

Despite the timid and restricted start, several universities sprung up in Africa following independence and were faced with the mounting task of providing a labour force that would serve the Independent States (Eisemon \& Salmi, 1993). Apart from having a mission to provide a labour force to serve the respective Independent States, newly established African universities were also charged to play a leading role in addressing the continent's outstanding problems of poverty, low production, hunger, unemployment, diseases and illiteracy (Mosha, 1986; Sawyerr, 2004). Taking the case of Cameroon for instance, the country had no university and many Cameroonians went abroad for university studies prior to independence in 1960, though such studies were poorly adapted to meet the needs of the Africa continent in general and Cameroon in particular (Njeuma et al., 1999). After independence, Cameroon faced an immediate need for trained senior civil servants to fill some of the positions that had hitherto been occupied by expatriates. The Federal University of Cameroon which evolved from the National Institute for Universities Studies established in 1961 and later renamed the University of Yaoundé had as urgent goal to meet the needs of the nation (Ngu \& Kwankam, 1992). Given the escalating need to decongest and decentralise the University of Yaoundé, Cameroon's Higher Education underwent a series of reforms which accounts for the eight State universities the nation currently has. Although the rising demand in university education and increase in enrolment meant that Cameroonian universities have seen a surge in the number of graduates being released to seek for jobs, there has not been a corresponding rise in the rate of graduate employment (Neneh, 2014). This is worrying, given that the current dilemma of graduate unemployment falls within the shadow of the university reforms of 1993 which also had as goal the professionalisation of higher education with an intention to produce graduates with the capacity needed by the private sector and the public service (Njeuma et al., 1999). In spite of several attempts by the State to curb the 
rise in youth unemployment, Cameroon universities still face the challenge of high rate of graduate unemployment. This article therefore sets out to explore the subject of graduate unemployment within a confined context in Cameroon.

\section{Methodology and Contextual Background}

The research underpinning this article can best be described as a qualitative study. The deliberate choice to adopt a qualitative approach was informed by the need to give participants an opportunity to have their voices heard. Employing conventional quantitative methods to the research would have inhibited the intention of giving participants the latitude to articulate their ideas. Thus, a single interpretive case-studly research design was adopted. Given that a case study will typically utilise multiple ways of collecting data (Mackenzie \& Knipe, 2006; Yin, 2009), the research employed semi-structured interviews and two focus group discussions from the $25^{\text {th }}$ of March to the $1^{\text {st }}$ of June 2013 to capture the voices of 31 participants drawn from dlisparate backgrounds.

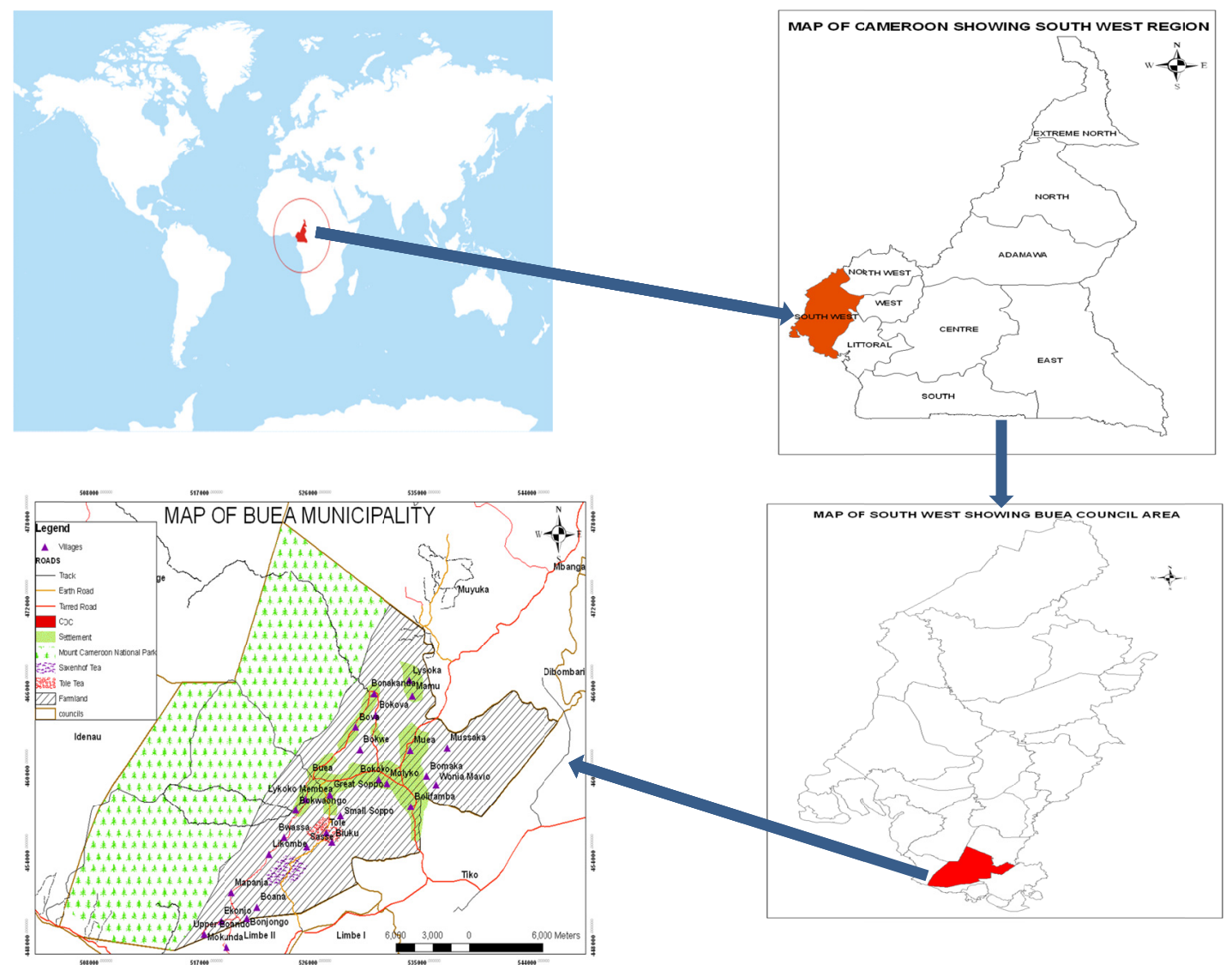

Figure 1. Illustration of the municipality of Buea

The site of the research was the municipality of Buea in Cameroon. It is worth noting that the government of Cameroon carved out administrative units into villages, towns, cities, municipalities, divisions and regions. The municipality is situated in the South West Region which is one of two English Speaking regions of Cameroon. It is made up of eighty-five villages spread across a surface area of $870 \mathrm{Sq} . \mathrm{km}$ with a total estimated population of above 200,000 inhabitants. The principal ethnic group in the municipality is Bakweri with a majority of them residing in the villages. The urban but cosmopolitan setting within the municipality is the town of Buea located at the foot of Mount Cameroon, which is the highest mountain in West and Central Africa. Historically, it was the capital of German Kamerun during German colonial rule. It later became capital of Southern Cameroons under British colonial rule, the capital of the Federated State of West Cameroon, and now regional capital of the South West Region. The majority of the inhabitants rely on agriculture (small scale farming) as a source of livelihood. English and French are two official languages used for general interaction while "pidgin" is the lingua franca. The municipality also consists of a State university created in 1993. The university has a student enrolment of over 12,000, and about 300 permanent and 200 part-time staff (UB, 2014). A different municipality and perhaps 
in the French speaking part of Cameroon could have been chosen for the research but was decided against due to the language barrier and the potential additional costs of securing translations. Figure 1 illustrates the position of the municipality of Buea in the world.

During the enquiry process, participants were invited to explore and describe their own understandings and definitions of the university and its role within their local community. Participants' contributions were transcribed and thematically analysed (Ryan, 2003). Direct quotations from participants have been inserted in the article to justify the different themes, with each quotation bearing the pseudonym of the participant, the gender, the age range, his/her village of residence and the date the interview or focus group discussion was conducted.

From the responses gathered, the university was construed as a) an educational and teaching centre b) a place to acquire prestige and status c) a venue for capacity building in order to gain employment and d) a place for intellectual and personal development amongst others. Whilst the subject of the university being seen as a venue for students to gain capacity in order to secure employment was a recurrent theme, it is also in the interest of this article to probe this subject further.

\section{University for Capacity Building and Employment}

Universities have been very useful in providing the human resources needed to serve in public and private sectors worldwide (Elliots et al., 1996; Eisemon \& Salmi, 1993). Even though the first university established in Cameroon had the mandate to provide a labour force to serve the demands of the newly independent nationCameroon (Njeuma et al., 1999); yet, many decades after independence, participants' responses revealed that university education in Cameroon is still being overwhelmingly regarded as a gateway to employment. Respondents uncovered how many sponsors of university students in Cameroon rely on very small scale farming and other menial tasks to generate the funds needed to support a child or loved one undergo university education with the intention that upon completion of studies, the graduate would be gainfully employed and begin to assist other loved ones economically. In this regard, many participants emphatically stated that the university should demonstrate responsibility in ensuring that graduates are job or employment ready in order to guarantee their ability for self-reliance and readiness to assume family responsibilities. This may not be considered surprising given the revealed challenging circumstances sponsors endure in order to see a loved one through university education due to widespread poverty and the fragile economy of the nation.

\subsection{Graduate Employability for Self-Reliance}

In a deliberate move to convey a message when asked the purpose of university education, a community participant who was divorced and had two dependents stated: "If it is not to have a job then what is the essence of a child going to the university?" (Agnes, female, 51-60, Bokwai, 06-04-2013). Given this quotation and the desire expressed by many other participants to see university graduates employed or find jobs, it was evidently clear that one of the underlining reasons points to the notion of "self-reliance". But what is "self-reliance"? The following quotation from a community participant who relied on small scale farming to take care of her twenty-six dependents illustrated this notion:

"When we the parents send our children to the university, it is that they should study and have something to do; If I, as a struggling farmer spend money and my child goes to the university and comes out, and there is no job, then the child turns to me and says 'mummy I want a pair of shoes or bathing lotion'; it does not sound well. The weight of financial burden you thought had been uplifted from your shoulder by sending that child to the university to study and pick up a job returns to you again. This is because the child cannot find a job, thus continuing to rely on you for provision of his/her basic needs" (Docas, female, 31-40, Bokuva, 03-05-2013).

The key message communicated by this participant can be construed to be the need for university graduates to be employed in order for them to be self-sufficient or demonstrate an ability to provide for their personal needs. It can be argued that rather than graduates exercising continuous reliance on their "struggling" parents or sponsors, these sponsors will be relieved of the financial burden of not only sponsoring a student at the university but also meeting his or her daily exigencies due to the opportunities graduate employment brings. To corroborate this notion of self-reliance, another respondent who was involved in small scale farming in one of the remote communities underscored: "The mother thinks the child should have finished studying at the university and got a good job and started to provide his or her needs and the needs of other family members but he or she comes out of the university and continues to be a burden and the both of you are just looking at each other. It does not make sense if he is unable to find a job when you know that he is educated. If he is educated and is not using his degree to earn a living, it does not mean anything" (Helen, female, 51-60, Bokwai New Layout, 05-05-2013).

From the narrative of this participant and many others captured within the enquiry process, it can also be 
underscored that the reason articulated for graduate employment is not limited to self-reliance but also included the need for employed graduates to assume family responsibilities. A strong link can therefore be uncovered between participants' desire for graduate employment and the concept of the family.

\subsection{Graduate Employability to Assume Family Responsibility}

In Africa in general and in Cameroon in particular, there is a strong sense of the family in almost every sector of social life. Family members tend to stick together and assist one another economically, morally and spiritually underpinned by a communal spirit of solidarity. This solidarity also aligns with the Ubuntu ideology expressed in many African communities. According to Makgoba (1996), Ubuntu's uniqueness is underpinned by its emphasis on the respect for the non-material order that exists in and amongst people. It fosters respect within humankind and for the environment; it is spiritually inclined; it is non-racial; it accommodates other cultures, and it is an invisible uniting force amongst Africans (Enslin \& Horsthemke, 2004). It can be seen as a value system which provides the source of many actions and attitudes in African communities.

As an African way of viewing the world, Ubuntu represents an alternative to individualism and competiveness in western communities by underlining the need for care, hospitality, respect and responsibility towards one another. Given this context, many community participants associated graduate employment with family solidarity. A family member who succeeds in a venture is often considered the success of the family and families can be seen relying on a member's economic fortune. In many instances, the employed is the sole bread winner of the entire family, one who assumes most of the financial responsibilities associated with it. The following excerpt from a participant's response captures this understanding: "The mother thinks the child should finish studying at the university and gets a good job and starts to provide his or her needs and the needs of other family members" (Helen, female, 51-60, Bokwai New Layout, 05-05-2013). This participant suggested that graduates should find jobs so that they can provide the needs of the family. Being an African, it is no hidden secret that the burden of economic responsibility that rest on an employed graduate goes beyond his or her immediate family to also include extended family members. The nature of family economic responsibilities associated with graduate employability as captured by participants' narratives can be illustrated thus:

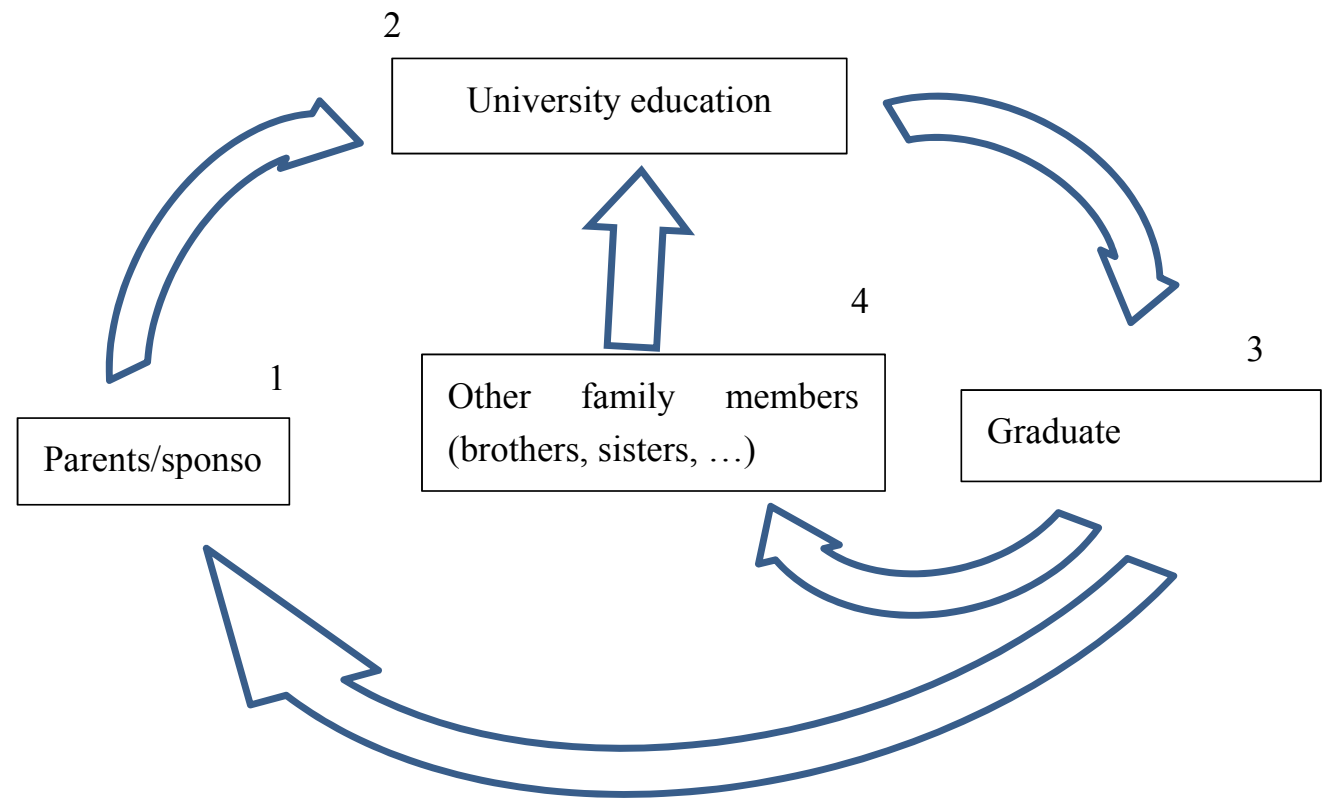

Figure 2. Family economic responsibilities associated with graduate employability

Figure 2 can be explained: Starting from the position of a sponsor/parent "1", he/she may engage in small scale farming or small business to sponsor a child at the university at position "2". The sponsor or parent struggles in the process to secure the required funds to enable his or her child enrol and go through university education with great anticipation that after graduation, the child would find a job or be employed at position " 3 " and eventually assist his/her siblings and other family members at position " 4 " to gain university education or meet any other 
socio-economic demands, which can in turn be of economic help to the parents or sponsors at position " 1 " who had hitherto gone through tough times to see her/him through university education and need to recuperate, or be able to assist other loved ones go through university education. In addition to economic responsibilities associated with graduate employability, a closer look at Figure 2 also reveals that university education can be positioned at the centre of its own sustainability, as well as the economic sustainability of families. This sustainability is depicted by the cyclic nature of the figure. From this perspective, it can be argued that the rate of graduate employability may spur university enrolment, and hence the sustainability of university education in communities. Not only would graduate employment provide a convincing reason why parents should send their children to the university but also, it provides an economic opportunity to afford the costs of seeing someone through it. In spite of participants' acknowledgment that the university carry the potential to build human capacities for employment, their responses also raised the concern of rise in graduate unemployment.

\section{The Dilemma of Graduate Unemployment}

Most of the participants interviewed on the nature of university education, pointed fingers to the lack of jobs for graduates. They overwhelmingly considered the university to be specialising in releasing graduates without prior preparation for employment or job creation and consequently contributing to the rising trend of youth unemployment in the community. The following excerpts from participants' responses revealed the nature of graduate unemployment in their communities:

"A lot of students graduate from the university and they do not have any employment. We the parents are taken aback because we expected that as soon as a child gets to that level, he or she should automatically obtain a job. But now we are realising that we spend more and more money each time in education and there is no solution" (Sherley, male, 51-60, Bonakanda, 10-05-2013).

"Many of them that leave from the university just come back to stay at home jobless. A mother goes to the farm and is harvesting cassava and the son who has graduated from the university is also fighting to harvest that same cassava. The child who has completed from the university is requesting money from the mother to buy soap. The mother is stressed up all the time" (Helen, female, 51-60, Bokwai New Layout, 05-05-2013).

"My daughter has just graduated with a degree in economics and she has a good GPA but what can she do? Is all theory and there is no job" (Margaret, female, 41-50, Bolifamba, 15-04-2013).

Whilst the strategic plan of the university at the centre of this article covering the period 2007-2015 underscores that one of the university's objective is to "make university programmes more professional and more responsive to market forces" (Mbuntum et al., 2008), the views of participants strongly suggested graduate unemployment is still a significant problem in the community. Given the state of this crisis and in an attempt to begin to seek ways to address it, it is essential to explore its underlining causes. In this light and from participants' narratives, the rise in graduate unemployment can be considered to have an endogenous root within the university and exogenous root outside the university. Endogenous factors responsible for graduate unemployment are factors the university can bring under its control whereas exogenous factors are factors largely beyond the reach of the university's means and capacity.

\section{Endogenous Factors Responsible for Graduate Unemployment}

Lack of student orientation, absence of course relevance and lack of practical skills are some of the factors raised by participants to be responsible for the undesirable situation of graduate unemployment.

\subsection{Lack of Proper Orientation}

One participant suggested that the lack of proper orientation have led many students to embark on the wrong academic programmes at the university which resulted in the difficulty of finding a job, basically because there are no jobs in that academic field. This female student participant elaborated: "You would notice that some students before being enrolled into the university are not orientated. When they are not orientated, they come in and they study something. But when you study something that the community is already saturated with or may not have immediate need of, you will automatically have some graduates jobless" (Susan, female, 21-30, Molyko, 12-04-2013). Whilst students can benefit from parental counselling or the advice of a loved one before university enrolment, it can be suggested that the university can also set up a unit to present opportunities for counselling to students caught up at the crossroad of confusion or doubt about which academic path to pursue, which have accompanying employment prospects. However, when many of the participants spoke about graduate employment, it was noticed that the idea of employment they conveyed was one that centres on being recruited by the private or public sector rather than on being self-employed. Accordingly, having a relevant orientation could lead to a change of mind set and prospective graduates can acquire skills for job creation or 
self-employment. One student participant sustained this argument by maintaining that the youths of Cameroon should depart from the idealistic position of seeking for jobs that would enable them to sit in offices. He elaborated: "There are other forms of employment; you must not only sit in an office as a lawyer or a doctor" (Lucas, male, 21-30, Molyko, 12-04-2013). Although the university at the centre of this research has staff members who were recruited to provide guidance and counselling to students in need, how effectively the service is running is worth exploring.

\subsection{Absence of Course Relevance}

It was noted that some students enrolled at the university due to the extrinsic benefit of securing the employment opportunities a particular academic degree presents. One female student on an agricultural course maintained: "I wanted to do Agriculture because of the employment prospects it offers. Self-employment, employment with the private sector, and employment with the government are possible options after my studies. If I apply the skills I have acquired here as a self-employer, that is, doing my own farming, I will still make a lot of money and earn a living" (Sophie, female, 21-30, Molyko, 19-04-2013). This was the scenario of a student who saw the need to enrol on an academic programme which provides a prospect for employment after completion. Enrolling on an academic programme like Agriculture may guarantee employment, even as the economy of Cameroon largely relies on the agricultural sector. An analysis of the contribution of the various economic sectors to Cameroon's 2009 real economic growth of $1.8 \%$ reveals that food crop production made the most contribution with a $0.9 \%$ (Fouda, 2012). Not all programmes at the university were seen in the same light. One male student participant noted:

"About one quarter of academic programmes at the university are not useful in the contemporary world, they are not profitable and as such, it makes it difficult to get a job, whereas, if half of the population at the university is orientated towards subjects like the sciences, technology and agriculture, it will help completing students to at least be self-employed. Looking at the Cameroonian society, I think our main source of livelihood is agriculture and the majority of the students of the university should be orientated towards it and even technology because globalisation has made technology to gain ground in the developing world" (Lucas, male, 21-30, Molyko, 1204-2013).

This assertion suggested the need for the university to run academic programmes which are relevant to the local community but also globally significant. The university may therefore need to keep pace with changing local and global market demands and trends and train/educate students suited for these changes. To corroborate the need for academic programmes at the university to also demonstrate global relevance, one female participant maintained that the university should "enlarge its scope and diversify its programmes. They should open the students not only to the Cameroonian community but to communities abroad" (Susan, female, 21-30, Molyko, 12-04-2013). This underscores a desire for the university to position prospective graduates such that they are able to maximise the advantages of globalisation by being able to also compete for jobs or demands out of the country. Whilst the number of graduates from Cameroonian universities exceeds the demand for new recruits, it would be beneficial if graduates are able to trade their skills and abilities abroad. Furthermore, where training programmes at the university are not relevant to the needs of both local and global markets, there is need for reorientation of such programmes for suitability.

\subsection{Lack of Practical Skills}

In addition to revealing their desire to see university education as relevant to local and global markets, some participants suggested that such relevance can be enhanced when practical components are associated with each academic programme. One female university student suggested: "The university needs to bring in more practical elements into their academic programmes. It has been theory, theory, and you discover how boring it is the more you remain in class. We do not even know what we are going to face outside. They need to widen the scope a little bit" (Pauline, female, 21-30, Molyko, 12-04-2013). The view of this participant can be said to also fall in line with the notion of the engaged scholarship propounded by Ernest Boyer (1996) where he argued that scholarship should not be confined to theory but should also find expression on the field through engagement. Engaging students in practical activities, tend to give them the opportunity to apply classroom knowledge in a real world or practical situation and this has the potential to prepare them for life after studies. Furthermore, experience enhances learning (Dewey, 1938) by promoting reflective and critical thinking.

Whilst these endogenous factors responsible for graduate unemployment can be addressed by the university's capacity, there are other factors termed exogenous factors which the university could find challenging to address as they do not fit so much within its remit. 


\section{Exogenous Factors Responsible for Graduate Unemployment}

Inadequate facilities to conduct training, as well as public corruption, heavy taxes and cumbersome governmental processes are some of the exogenous factors raised by participants which are responsible for graduate unemployment.

\subsection{Inadequate Facilities}

The university at the nucleus of this article is State-owned and relies heavily on State subsidies for its recurrent and investment expenditures. The current economic situation of the country has led to dwindling subsidies to State universities, irrespective of an increasing need for investment in facilities that would enhance the capacity building of young Cameroonians for employment and societal transformation. This situation has affected the quantity and quality of infrastructures at State universities. One student participants noted: "We do not have the necessary facility to foster our learning so that we can come out with skills to serve the society. I think that if the university has a good science department with equipment, it would be of help to us" (Lucas, male, 21-30, Molyko, 12-04-2013).

Whilst it can be argued that the university's ability to secure relevant facilities to enhance the training of young Cameroonians with transferable skills needed for gainful employment after their studies and effective contribution to the country's GDP is dependent on the quality of financial or budget management at the level of the university, it can be argued that it is also largely dependent on State allocations. This article therefore suggests that the State may need to revisit its budgetary allocations by prioritising university education and investing significantly in its infrastructures, facilities and capacity building of the students, as well as the staff.

\subsection{Public Corruption, Heavy Taxes and Cumbersome Governmental Processes}

Although employment may be regarded as work under contractual arrangements involving economic benefits (Jahoda, 1982), it is not restricted to being recruited to work in a public or private sector, but also involves being self-employed. Self-employment can be expressed through the setting up of businesses. Entrepreneurs and sole proprietors setting up businesses, would normally seek a relevant environment and climate that would enable their businesses to flourish and to maximise profit. According to one student participant, this is not the situation in Cameroon where he maintained the political and economic climate is hostile to sole proprietorship. He posited: "The government of the country is corrupt which makes it difficult to even start a business. The procedure to start a new business is cumbersome, coupled with heavy taxes. The system should facilitate private investments" (Paul, male, 21-30, Molyko, 02-04-2013).

This narrative suggests that the university can impart students with entrepreneurial skills for self-employment but State policies and corruption can make it difficult for them to engage in profitable ventures like starting up a new business. Corruption in Cameroon is a widespread concern and the country was ranked 144th out of 177 countries in the 2013 Corruption Perceptions Index (CPI, 2013). Whilst many participants expected the university to equip students with what it takes to seek or create jobs, they also want the machinery of the State to be less corrupt and the process of registering a new business be rendered less burdensome and bureaucratic. Furthermore, as a means to curb unemployment, this article maintains the need for new businesses not to be allowed to crumble under the weight of heavy taxes. Rather, the State and its policies can provide incentives to enable new businesses to emerge and grow to the point whereby they can begin to make realistic tax contributions to the system which will not be counterproductive to their long term profitability and survival.

\section{Repositioning the University as a Gateway to Employment}

It suffices to highlight that the State-owned university at the hub of this article has a mandate to enhance graduate employability. However, there is mounting evidence that depicts the need for the university to be repositioned to act accordingly. A number of factors emerged from participants' narratives on how the university can help students to be employed upon finishing their studies. Some of these factors which have been mentioned before in the previous section will be reiterated in addition to new insights.

\subsection{Customising Education and Training to Serve the Needs of the Job Market}

A significant number of participants emphasised the need for education and training at the university to be tailored to address the needs of the job market. They suggested that the university can connect with the civil society, the industrial world or other services in the wider community so that academic programmes can be customised to address their concerns. Another benefit of customising academic programmes could be that if a student, for example, reads English Literature at the university, something can be added to it such as teaching of English Literature, editing or creative writing to provide an opportunity to demonstrate the relevance of the subject to the society. Furthermore, the university could also work with community partners to negotiate 
academic pathways, modules and endorsement consistent with areas of community/market needs. However, these measures should also take into account the need for quality and standard in conformity with regulations for institutional conferment of awards.

In addition, as many participants picked up issues with the educational system at the State-owned university in the municipality, one respondent suggested that foreign models of education which are obsolete and no longer relevant in serving the developmental or market needs of the community should be replaced with an updated educational system which is relevant to national and local contexts. This participant went on to interrogate the relevance of the Anglo Saxon system of education adopted by the university at the centre of this project. He probed:

"Has the Anglo-Saxon system helped our development, in terms of meeting our needs or hindering it? If you tell a boy with Mathematics, Chemistry and Physics at the Advanced Level who can read electronics normally, that he would not enter the university because of failure in Ordinary Level English, does that not hinder his development? As an English teacher, I will say that the English examination at the Ordinary Level which I set and which I mark and which is an artificial test of language cannot be given priority over the language which he used to pass his Advance Level which is applied English. This is education we are talking about. We are talking about development to bring out skills from people not because the English man qualifies us for it but because we need those skills to develop our environment" (Gregory, male, 51-60, Wokoko, 28-04-2013).

To clarify, the State-owned university in the municipality was established to emulate the standards of a traditional British university in terms of governance, structure and operations. As the participant above posited, having the required result in an English Language test is a prerequisite for admission into the university irrespective of the fact that one may have passed other subjects conducted in English at the General Certificate of Examination (GCE) Ordinary and Advance Levels organised by the GCE Board. It is worth to note that Cameroon is multilingual, and English is one of official languages, spoken by 30\% of the population (PRC, 2014). Irrespective of the fact that the English Language is an official language and Cameroon has historical ties with Britain, the participant above argued that the label of "Anglo-Saxon" over the State university has become a barrier to the community's development and the potential for graduates to integrate into the society and be agents of transformation. On this basis, the concept of Anglo-Saxonism over the local university can be argued to have alienated many prospective students from university education because of failure to meet the English Language requirement and given that Higher Education has the potential to enhance one's capacity for participation in the nation, as well as community building, this "language entry" barrier could be removed or simplified. By simplification, one participant underscored the need for the university to examine its operations and modify it in order to enhance access to Higher Education and to enable its educational system to serve local market needs instead of adopting a foreign system of education which is deficient in contributing to local community development and the needs of the citizenry. In accordance with this view, this article suggests that the university can revise the Anglo-Saxon model of education it has adopted to suit relevant markets and graduate employability within a context of sustainability.

\subsection{Demonstrating Consciousness and Providing Students with Adequate Counselling}

Participants' narratives also highlighted the need for the university to demonstrate awareness and desire for affecting the community and its ecological landscape through the quality of its graduates. The university can be a service oriented agent of education and that consciousness could take a level of emphasis. One participant posited that "to be awarded a $\mathrm{PhD}$ by the university does not mean that one is useful because a $\mathrm{PhD}$ needs an HPD which means 'Help People Develop'. If one's PhD does not have a corresponding HPD, it simply implied one had but a PHD which means 'Pull Humans Down"' (Gregory, male, 51-60, Wokoko, 28-04-2013). From this insight, the need for university education to have an ethical and moral dimension which seeks to contribute to improving the livelihood of community residents can be suggested.

Furthermore, the consciousness of contributing to societal transformation can be fostered through a strong counselling unit at the university to assist students with choice of career path as earlier noted. Although it was observed that the university has professional counsellors recruited by the State to serve this purpose, they are often redeployed into other units of the university which tend to invalidate their initial role. Therefore, it can be suggested that there is a need for the university to recognise the role of these counsellors and let the students maximise their services for proper orientation and guidance towards profitable careers.

\subsection{Providing Entrepreneurial Skills for Job Creation}

In order to address the need for graduate employment, some participants advocated that students should be given entrepreneurial skills to not only look for jobs after completion of studies but also to create one and be 
self-employed. The following interview transcript with a tomato farmer (Martin, male, 31-40, Molyko, 26-04-2013) emphasises this:

Q: what do you want the university to do in the future?

Martin: They should go more vocational, if they go more vocational then it would be so wonderful

Q: What is the benefit of vocational training?

Martin: Somebody being trained will not come out and seek employment; they will create employment for others

Q: So indirectly you want the university to give people entrepreneurial skills?

Martin: Yes

Although the above mentioned factors can boost graduate employment, it can also be argued that the purpose of university education should not be limited to employment. There is therefore a need to strike a balance between university education for personal/intellectual development or some other reason and university education for local/global market consumption. Whilst liberal education may be concerned with the cultivation of the mind as the business of the university, Newman asserts that some great minds would be very slow to understand this. According to Newman (1955), "they insist that Education should be confined to some particular and narrow end, and should issue in some definite work, which can be weighed and measured. They argue as if everything, as well as every person, had its price; and that where there has been a great outlay, they have a right to expect a return in kind. This they call making Education and Instruction 'useful', and 'utility' becomes their watchword" (1955, p. 77). This assertion is consistent with the views of many participants who called for university education to guarantee a foothold in the job market for graduates. Moreover, the subject of graduate employability should not be limited to graduates finding jobs in the local community but should also incorporate the global community. The limited size of a local job market means that it can easily become saturated with too many applicants competing for few job vacancies, hence the need for the university to train students who can also their skills and knowledge abroad or be competitive in the global market.

\section{Conclusion}

Even though the role of the university is increasingly being subjected to scrutiny, a university can be perceived to have the potential which enables it operate as a gateway to employment within a context of poverty, scarcity and fragile economy. On the basis of findings from research data, this article argues that graduate employment can 1) foster self-reliance as graduates would no longer depend on sponsors or parents as a source of livelihood, and 2) contribute to the economic sustainability of families as employed graduates would be able to earn income and economically assist both immediate and extended family members. Given that the family can be construed as the basic unit of a society or community, graduate employment also has the potential to enhance the economic prosperity of a community and a nation. Although a university can be perceived to have the capacity to enhance the employability of its graduates, it could take appropriate measures to enforce and operationalise this capacity. By connecting the university with relevant segments of the local and global communities so that academic programmes at the university can be customised to serve local and global interests; adopting and operationalising an appropriate counselling unit to provide career guidance to students and fostering entrepreneurial capabilities for self-employment, the university can make effective contributions towards graduate employability and also maintain its ethos of fostering academic rigour and quality. In addition, the university's efforts toward enhancing graduate employability can be complemented with relevant inputs from State and the community within a framework of collaborative engagement and shared interests.

\section{References}

Boyer, E. L. (1996). The Scholarship of Engagement. Journal of Public Service and Outreach, 1(1), 11-20.

CPI. (2013). Corruption Perceptions Index 2013. Retrieved October 07, 2014 from http://cpi.transparency.org/cpi2013/results/

Dewey, J. (1938). Democracy and Education: An Introduction to the Philosophy of Education. New York: Macmillan.

Eisemon, T. O., \& Salmi, J. (1993). African Universities and the State: Prospects for Reform in Senegal and Uganda. Higher Education, 25(2), 151-168. http://dx.doi.org/10.1007/BF01384746

Elliot, J., Francis, H., Humphreys, R., \& Istance, D. (1996). Communities and their Universities: The Challenge of Lifelong Learning. London: Lawrence \& Wishart Limited.

Enslin, P., \& Horsthemke, K. (2004). Can Ubuntu provide a model for citizenship education in African 
democracies? Comparative Education, 40(4), 545-558. http://dx.doi.org/10.1080/0305006042000284538

Fouda, M. S. (2012). A Pragmatic Approach to Policy for Sustainable Growth. In E. Aryeetey, S. Devarajan, R. Kanbur, \& L. Kasekende (Eds.), The Oxford Companion to the Economics of Africa (pp. 457-459). Oxford: Oxford University Press.

Jahoda, M. (1982). Employment and Unemployment: A Social Psychological Analysis. Cambridge: The Press Syndicate of the University of Cambridge.

Mackenzie, N., \& Knipe, S. (2006). Research delimmas: Paradigms, methods and methodology. Issues in Educational Research, 16(2), 193-205.

Makgoba, M. W. (1996). In search of the ideal democratic model for SA. Sunday Times, 23.

Mbuntum, F., Tiayong, C., Tendo, J., Foba, F. N., Talla, R., Tita, C., \& Mbake, M. (2008). The University of Buea Strategic Plan 2007-2015. Buea: Vincent P.K. Titanji.

Mosha, J. H. (1986). The role of African universities in national development: a critical analysis. Comparative Education, 22(2), 93-109. http://dx.doi.org/10.1080/0305006860220202

Neneh, B. N. (2014). An Assessment of Entrepreneurial Intention among University Students in Cameroon. Mediterranean Journal of Social Sciences, 5(20), 542.

Newman, J. H. (1955). The Idea of a University. London: Cambridge University Press.

Ngu, L. J., \& Kwankam, Y. S. (1992). At what price higher education in Africa? A case study of higher education systems in Cameroon. Ottawa: International Development Research Centre.

Njeuma, D. L., Endeley, H. N., Mbuntum, F. F., Lyonga, N., Nkweteyim, D. L., Musenja, S. \& Elizabeth, E. (1999). Reforming a National System of Higher Education: The Case of Cameroon. Washington: ADEA Working Group on Higher Education.

PRC. (2014). Presentation of Cameroon. Retrieved October 06, 2014 from https://www.prc.cm/en/cameroon/presentation

Ryan, W. G. (2003). Techniques to Identify Themes. Field Methods, 15(1), 85-109. http://dx.doi.org/10.1177/1525822X02239569

Sawyerr, A. (2004). Challenges Facing African Universities: Selected Issues. African Studies Review, 47(1), 1-59.

UB. (2014). About UB. Retrieved October 06, 2014, from http://ubuea.cm/about/

Yin, R. K. (2009). Case study research: Design and methods (4th ed.). Thousand Oaks, CA: Sage.

\section{Copyrights}

Copyright for this article is retained by the author(s), with first publication rights granted to the journal.

This is an open-access article distributed under the terms and conditions of the Creative Commons Attribution license (http://creativecommons.org/licenses/by/3.0/). 